\title{
This is our legacy
}

\section{MARGE PIERCY}

How will they curse us, the $3^{\text {rd }}, 4^{\text {th }}$ generations, the ones that survive the deaths we left them?

How could we explain the world on fire, species wiped out daily, oceans with more plastic than fish?

That we let a corrupt man stomp refugees fleeing rape, murder and hunger that we let him set blazes

no one could put out. We saw the cliff ahead We were well warned We took everyone over.

That was how our world ended, in lies and greed vast and numerous maggots dining on the corpse of hope. 